\title{
Survei Tingkat Pengetahuan tentang Keamanan Penggunaan Obat pada Ibu Menyusui di Puskesmas Sumbersari Kabupaten Jember
}

\author{
Ika Norcahyanti*, Antonius Nugraha Widhi Pratama, Hairunnisyah Asfarina \\ Fakultas Farmasi, Universitas Jember, Jember, Indonesia
}

\section{INFO ARTIKEL}

Sejarah artikel:

Penerimaan

naskah: 5 Maret

2018

Penerimaan

naskah revisi: 7

Juni 2018

Disetujui untuk

dipublikasikan: 28

Juni 2018

Kata kunci :

Air Susu Ibu,

Kuisioner, Obat

\section{A B S T R A K}

Pada masa menyusui seorang ibu dapat mengalami berbagai keluhan atau gangguan kesehatan yang membutuhkan penggunaan obat, sehingga banyak ibu yang sedang menyusui menggunakan obat yang dapat memberikan efek yang tidak dikehendaki pada bayi yang disusui. Beberapa obat dengan karakteristik tertentu dapat diekskresikan melalui ASI. Karakteristik yang dimaksud antara lain adalah obat yang mudah larut dalam lemak, obat yang memiliki berat molekul kecil, obat yang terionisasi, dan obat yang berikatan lemah dengan protein plasma. Tingkat pengetahuan ibu menyusui akan keamanan obat merupakan faktor yang penting untuk menjaga keselamatan bayi. Apabila ibu menyusui memiliki tingkat pengetahuan yang baik akan keamanan obat sepanjang menyusui, maka bayi dapat terhindar dari bahaya efek samping obat. Penelitian ini merupakan penelitian survei dengan desain cross sectional terhadap 100 orang responden di Puskesmas Sumbersari Kabupaten Jember. Sampel responden dipilih menggunakan teknik purposive sampling. Sebelum kuesioner dibagikan kepada responden, terlebih dahulu dilakukan uji validitas serta uji reliabilitas. Kategori tingkat pengetahuan ibu menyusui tentang keamanan obat dibagi menjadi 3, yaitu kategori rendah, sedang, dan tinggi. Acuan untuk kategori tersebut, diambil dari nilai rata-rata \pm SD pengetahuan ibu menyusui. Analisis deskriptif menunjukkan nilai rata-rata \pm SD yaitu sebesar $6,5 \pm 2,4$, sehingga untuk nilai di antara 4,1-8,9 termasuk dalam kategori sedang. Nilai < 4,1 termasuk ke dalam kategori rendah dan nilai > 8,9 termasuk ke dalam kategori tinggi. Hasil penelitian menunjukkan bahwa ibu menyusui yang memiliki tingkat pengetahuan rendah sebesar $20 \%$, tingkat pengetahuan sedang sebesar $57 \%$, dan tingkat pengetahuan tinggi sebesar $23 \%$. Pada penelitian ini juga dilakukan pengelompokan obat yang digunakan oleh responden ditinjau dari tingkat keamanannya berdasarkan ketentuan WHO tahun 2003. Hasilnya adalah di antara obat-obat yang digunakan oleh responden, terdapat obat yang masuk ke kelompok obat dengan tingkat keamanan kategori satu (amoksisilin, asam mefenamat, dekstrometorfan $\mathrm{HBr}$, ibuprofen, parasetamol, dan tetrasiklin), obat dengan tingkat keamanan kategori dua (asetosal dan efedrin $\mathrm{HCl}$ ), serta obat dengan tingkat keamanan kategori tiga (klorfeniramin maleat).

\section{Survey on Knowledge Level of Drug Usage Safety to Breastfeeding Mother at Puskesmas Sumbersari Jember}

Keywords:

Breast Milk, Questionnaires, Medications

\begin{abstract}
A B S T R A C T
On lactation a mother can experience a variety of health complaints or disorders that require the use of the medicine, so many mothers who are breastfeeding using drugs that can give undesirable effects on the baby's feedings. Some drugs with certain characteristics can be excreted through breast milk. The characteristics referred to, among others, is a drug that is easily soluble in fats, a drug that has the weight of small molecules, ionized drugs, and drugs that bind weakly with plasma proteins. The level of knowledge of nursing mothers will drug safety is a crucial factor to safeguard the safety of the baby. When nursing mothers have a good level of knowledge will be drug safety throughout lactation, so baby can escape from the dangers of drug side effects. This research is a survey research with crosssectional design against 100 people respondents in Sumbersari Clinics at Jember Regency. The sample of respondents is selected using a purposive sampling technique. Before the questionnaires distributed to respondents, first conducted the test validity and reliability tests. Category level of knowledge of nursing mothers about the safety of the drugs are divided into 3 categories, namely low, medium, and high. Reference to that category, taken from the average rating \pm SD knowledge of nursing mothers. Descriptive analysis shows average values \pm SD i.e of $6.5 \pm 2.4$, so for a value of between 4.1-8.9 are included in the category of being. Values smaller than 4.1 fall into the low category and values greater than 8.9 fall into the high category. The results showed that breastfeeding mothers who have low knowledge level of $20 \%$, the level of knowledge being of $57 \%$ and a high level of knowledge of $23 \%$. Research is also done in which the drug is used by respondents in terms of security level based on the provisions of the WHO year of 2003. The result is among the drugs used by the respondents, there are drugs that go into drug groups with category one level of security (amoksisilin, dekstrometorfan $\mathrm{HBr}$, mefenamic acid, ibuprofen, paracetamol, and tetracycline), drugs with a the security level of the category two (asetosal and ephedrine $\mathrm{HCl}$ ), as well as a drug with a security level of category three (klorfeniramin maleate).
\end{abstract}




\section{Pendahuluan}

Menyusui menurut World Health Organization (WHO) merupakan suatu proses yang normal untuk bayi karena Air Susu Ibu (ASI) mengandung nutrisi yang dibutuhkan untuk pertumbuhan dan perkembangan bayi. ${ }^{45}$ Kandungan nutrisi dalam ASI, terdiri atas laktosa sebesar 77 $\mathrm{g} / \mathrm{L}$, lemak $45 \mathrm{~g} / \mathrm{L}$, dan protein $11 \mathrm{~g} / \mathrm{L} .{ }^{40} \mathrm{WHO}$ telah mengkaji bahwa waktu optimal pemberian ASI eksklusif adalah sejak bayi lahir sampai berusia 6 bulan. Saat menjalani masa ASI ekslusif, bayi hanya menerima ASI tanpa cairan lain atau zat padat bahkan air putih. ${ }^{47}$ Pemberian ASI pada bayi dapat memberikan manfaat yaitu dapat melindungi bayi dari berbagai infeksi seperti otitis media, infeksi saluran pernapasan, infeksi saluran pencernaan, dan infeksi saluran kemih. ${ }^{40}$

Pada saat seorang ibu sedang berada dalam masa menyusui melalui pemberian ASI, seorang ibu dapat mengalami berbagai keluhan atau gangguan kesehatan yang membutuhkan penggunaan obat. Sehingga, banyak ibu yang sedang menyusui menggunakan obat yang dapat memberikan efek yang tidak dikehendaki pada bayi yang disusui. ${ }^{16}$ Beberapa obat dengan karakteristik tertentu dapat bercampur ke dalam ASI. Karakteristik yang dimaksud antara lain adalah obat yang mudah larut dalam lemak, obat yang memiliki berat molekul (BM) kecil, obat yang terionisasi, dan obat yang berikatan lemah dengan protein plasma. $^{30}$ Obat yang bersifat larut dalam lemak akan semakin banyak masuk ke dalam ASI karena akan sangat mudah untuk melewati membran sel alveoli payudara yang dibatasi oleh lipid. Kelarutan obat dalam air dan dalam lipid menjadi faktor penentu transfer obat selama laktasi. ${ }^{40}$ Obat yang memiliki berat molekul besar tidak dapat melewati membran kapiler, contohnya seperti heparin yang memiliki berat molekul 6.000-20.000 Dalton. ${ }^{9}$ Kebanyakan obat yang memiliki berat molekul kecil seperti parasetamol $(<200$ Dalton) akan mudah melewati pori membran sel alveoli. Plasma darah memiliki pH sekitar 7,4 dan ASI memiliki pH sekitar 6,8 sehingga plasma relatif sedikit lebih basa daripada ASI. Obat yang bersifat basa lemah di plasma akan lebih banyak dalam bentuk tidak terionisasi serta mudah menembus membran alveoli dan kapiler payudara. Sesampainya di ASI, obat yang bersifat basa tersebut akan mudah terion sehingga tidak mudah melewati membran untuk kembali ke plasma. Fenomena tersebut dikenal sebagai "trapped ion". ${ }^{16}$ Obat yang terikat dengan protein plasma tidak dapat tersebar ke jaringan, seperti masuknya fenitoin yang cenderung tetap berada di dalam plasma. ${ }^{9}$ Hanya obat yang tidak terikat plasma yang dapat tersebar ke jaringan, contohnya adalah litium. ${ }^{20}$ Apabila obat dengan karakteristik tersebut diminum oleh ibu menyusui dan masuk ke dalam ASI, maka penumpukan obat di dalam tubuh bayi dapat terjadi dan dapat memberikan beberapa efek seperti efek terapeutik, efek toksik, dan efek samping. Dengan adanya berbagai macam efek obat seperti di atas, sebaiknya ibu menyusui mengetahui kandungan, manfaat, keuntungan, dan kerugian saat menggunakan obat. ${ }^{4}$

Ibu menyusui yang mengalami beberapa kondisi seperti depresi dan infeksi, berisiko menggunakan obat yang dapat terekskresi melalui ASI. Salah satu antidepresan yang diekskresikan melalui ASI adalah fluoxetin. Kondisi kolik dan sedasi dapat terjadi pada bayi yang ibunya mendapatkan terapi fluoxetin. ${ }^{13}$ Pada kasus infeksi, salah satu antibiotik yang diekskresikan melalui ASI adalah kloramfenikol. Penekanan sumsum tulang dapat terjadi pada bayi yang ibunya mendapatkan terapi kloramfenikol. ${ }^{26}$ Selain depresi dan infeksi, beberapa ibu menyusui yang melakukan swamedikasi juga berisiko menggunakan obat yang dapat memengaruhi kualitas dan kuantitas ASI. Seperti misalnya, pada beberapa obat kombinasi flu dan batuk yang digunakan dalam swamedikasi memiliki kandungan pseudoefedrin. Pseudoefedrin diketahui sebagai obat yang mampu menurunkan produksi ASI. ${ }^{1}$ Pengetahuan ibu menyusui akan keamanan obat merupakan faktor yang penting untuk menjaga keselamatan bayi pada masa menyusui. Apabila ibu menyusui memiliki tingkat pengetahuan yang baik akan keamanan obat sepanjang menyusui, maka bayi dapat terhindar dari bahaya efek samping obat.

Salah satu fasilitas layanan kesehatan yang dapat dimanfaatkan oleh ibu menyusui adalah Puskesmas. Puskesmas wajib melaksanakan kegiatan Posyandu di masing-masing tempat yang sudah ditentukan. Posyandu merupakan salah satu bentuk upaya kesehatan bersumber daya masyarakat yang bertujuan memberikan kemudahan kepada masyarakat untuk memperoleh informasi serta pelayanan kesehatan. $^{16}$ Di Kabupaten Jember sendiri terdapat 50 Puskesmas dan salah satunya adalah Puskesmas Sumbersari. Puskesmas Sumbersari merupakan Puskesmas yang memberikan pelayanan kesehatan pada ibu menyusui dengan jumlah paling tinggi. Berdasarkan laporan pada tahun 2016 jumlah ibu menyusui di Puskesmas Sumbersari mencapai 1.426 orang. Penelitian ini bertujuan untuk mengetahui tingkat pengetahuan ibu menyusui tentang keamanan penggunaan obat pada masa menyusui serta mengetahui keamanan obat-obat yang digunakan oleh ibu menyusui di Puskesmas Sumbersari Kabupaten Jember. Melalui penelitian ini diharapkan dapat menambah informasi dan pengetahuan bagi ibu menyusui tentang pentingnya keamanan penggunaan obat pada masa menyusui serta memberikan informasi kepada tenaga kesehatan dan masyarakat mengenai pentingnya memberikan informasi terkait penggunaan obat yang aman bagi ibu menyusui.

\section{Metode}

Penelitian ini merupakan penelitian non eksperimental dengan rancangan deskriptif cross sectional. Penelitian ini dilakukan dengan cara memberikan kuesioner tingkat pengetahuan kepada ibu menyusui. Data yang diperoleh akan digunakan untuk mengetahui tingkat pengetahuan tentang keamanan penggunaan obat pada ibu menyusui di Puskesmas Sumbersari Kabupaten Jember.

Pengambilan data dilakukan di Posyandu dan Puskesmas Sumbersari, Kabupaten Jember mulai bulan Juni-Juli 2017. Posyandu wilayah kerja Puskesmas Sumbersari terbagi dalam tujuh Kelurahan yaitu Sumbersari, Kranjingan, Karangrejo, Wirolegi, Antirogo, Kebonsari, dan Tegalgede. Analisis data dilakukan di 


\section{Fakultas Farmasi Universitas Jember.}

Populasi dalam penelitian ini adalah ibu menyusui yang terdaftar sebagai anggota Posyandu di Puskesmas Sumbersari, Kabupaten Jember. Pada penelitian ini sampel yang digunakan adalah semua sampel yang sudah memenuhi kriteria inklusi yang dibatasi oleh waktu (time limited), yaitu periode Juni-Juli 2017. Jumlah sampel minimal yang digunakan dalam penelitian ini adalah sebanyak 100 orang responden yang dihitung berdasarkan rumus berikut:

$$
\frac{\mathrm{Z}_{(1-\alpha / 2)}^{2} \mathrm{P}(1-\mathrm{P})}{\mathrm{d}^{2}}
$$

keterangan :

$\mathrm{Z}_{(1-\alpha / 2)(\text { deviat baku alfa) })=1,96}$

$\mathrm{P}($ estimasi proporsi $)=0,5$

$1-\mathrm{P}($ estimasi proporsi dari populasi yang tidak dikehendaki $)=0,5$ $\mathrm{d}($ presisi $)=0,1$

Pengambilan sampel dilakukan dengan menggunakan teknik purposive sampling.

Kriteria inklusi meliputi ibu menyusui di Posyandu dan Puskesmas Sumbersari Kabupaten Jember yang sedang memberikan ASI kepada bayinya tanpa memandang lama masa menyusui dan ibu menyusui yang bersedia diikutsertakan dalam penelitian ini, ditunjukkan melalui informed consent. Kriteria eksklusi pada penelitian ini, yaitu ibu menyusui yang tidak menjawab pertanyaan pada kuesioner dengan lengkap.

Cara perolehan data akan dilakukan melalui dua tahapan, yaitu penyebaran kuesioner dan dilanjutkan dengan pencatatan data. Data yang diperoleh kemudian akan disimpan menggunakan microsoft excel yang meliputi kode responden, data responden (paritas, usia, pendidikan, dan pekerjaan), riwayat keluhan pada masa menyusui, riwayat penggunaan obat, infomasi pemakaian obat, dan jawaban yang diberikan responden terkait tingkat pengetahuan. Kuisioner yang digunakan dalam penelitian ini juga melalui uji validitas dan uji reliabilitas. Uji validitas pada penelitian ini dilakukan menggunakan dua cara penilaian, yaitu content validity dan face validity. Uji reliabilitas pada penelitian ini menggunakan metode Split-half alpha dengan program SPSS. Setelah diuji dengan Split-half alpha, peneliti selanjutnya membandingkan nilai reliabilitas yang dihasilkan.

Dalam perhitungan data, dilakukan penilaian tingkat pengetahuan. Untuk tingkat pengetahuan yang terdiri atas 10 pertanyaan dikategorikan jawaban benar mendapat nilai 1 , jawaban salah mendapat nilai 0 , dan jawaban tidak tahu bernilai missing (.). Setelah jawaban sudah terkumpul, selanjutnya akan dilakukan perhitungan skor dan dikategorikan berdasarkan kategori yang sudah disiapkan. Kategori skor total dalam tingkat pengetahuan dibagi menjadi tiga yaitu tinggi, sedang dan rendah. Untuk keamanan penggunaan obat pada ibu menyusui, peneliti menggunakan ketentuan dari World Health Organization (WHO) tahun 2003 yang terdiri atas obat dengan tingkat keamanan kategori satu, kategori dua, dan kategori tiga.

\section{Hasil dan Diskusi}

Proses pengambilan data dilakukan di enam Posyandu di wilayah Kecamatan Sumbersari dan di Poli Kesehatan Ibu dan Anak (KIA) Puskesmas Sumbersari Kabupaten Jember. Data diperoleh berdasarkan jawaban kuesioner yang telah diisi oleh responden. Pengambilan data berlangsung pada bulan Juni-Juli 2017 dengan jumlah responden sebanyak 100 responden.

\section{Hasil Uji Validitas dan Reliabilitas Instrumen}

Uji validitas pada penelitian ini dilakukan dengan penilaian content validity dan face validity. Penilaian pada content validity dilakukan dengan cara meminta penilaian dari dua orang ahli terkait isi kuesioner, apakah sudah mampu mengukur apa yang hendak diukur pada penelitian ini. Penilaian pada face validity dilakukan dengan mengujicobakan kuesioner pada 30 orang responden. Face validity memiliki tujuan untuk melihat apakah setiap butir pernyataan yang diajukan peneliti pada kuesioner sudah dapat dipahami oleh responden penelitian.

Menentukan valid tidaknya suatu pernyataan yang diajukan dapat dilakukan dengan membandingkan nilai $r$ tabel dan nilai $r$ hitung. Jika nilai $r$ hitung lebih besar dari nilai $\mathrm{r}$ tabel maka pernyataan dianggap valid. Pada penelitian ini, karena jumlah responden yang digunakan sebesar 30 orang, maka nilai $r$ tabel yang digunakan adalah 0,361 dan hasilnya adalah semua pernyataan valid karena nilai $r$ hitung lebih besar dari nilai $r$ tabel yang telah ditentukan.

Uji reliabilitas instrumen juga dilakukan pada 30 orang responden yang sama saat melakukan uji validitas. Tujuan dilakukan uji tersebut adalah untuk mengetahui tingkat pemahaman responden, sehingga responden memiliki respon yang sama pada pernyataan serupa. ${ }^{10}$ Hasil jawaban dari 30 sampel pada 10 soal pengetahuan tersebut dihitung menggunakan program SPSS versi 16. Uji reliabilitas menggunakan metode Split-half alpha yang dilakukan dengan cara memberikan kuesioner satu kali saja. Hasil uji reliabilitas menunjukkan nilai $\alpha$ sebesar 0,78. Hasil penelitian menunjukkan bahwa, kuesioner yang dipakai dalam penelitian memiliki reliabilitas yang baik. Hal ini didasarkan pada nilai rentang $\alpha$ yaitu $\geq 0,7-0,9$, sehingga kuesioner dapat digunakan untuk penelitian lebih lanjut. ${ }^{10}$

\section{Tingkat Pengetahuan Ibu Menyusui}

Tingkat pengetahuan responden tentang keamanan obat diukur berdasarkan nilai yang diperoleh dari jawaban berdasarkan 10 soal pada kuesioner tingkat pengetahuan dengan nilai total yaitu 10. Kategori tingkat pengetahuan responden dibagi menjadi tiga, yaitu kategori rendah, sedang, dan tinggi. Acuan untuk kategori tersebut, diambil dari nilai rata-rata \pm SD pengetahuan responden. Analisis statistik deskriptif menunjukkan bahwa nilai rata-rata \pm SD 
yaitu sebesar 6,5 $\pm 2,4$ (Tabel 1), sehingga untuk nilai di antara 4,1-8,9 termasuk dalam kategori tingkat pengetahuan sedang. Nilai $<4,1$ termasuk ke dalam kategori tingkat pengetahuan rendah dan nilai > 8,9 termasuk ke dalam kategori tingkat pengetahuan tinggi. Dari total 100 responden hanya $23 \%$ yang masuk ke dalam kategori tingkat pengetahuan tinggi dan sebesar 56\% masuk ke dalam kategori tingkat pengetahuan sedang (Tabel 2 dan 3). Adanya perbedaan tingkat pengetahuan responden dapat dipengaruhi oleh berbagai faktor, antara lain karena daya ingat individu berbeda-beda dan pengetahuan yang didapatkan dari masing-masing responden juga berbedabeda. ${ }^{37}$ Pada pernyataan yang terkandung di dalam kuesioner bagian tingkat pengetahuan adalah pernyataan umum mengenai keamanan dalam menggunakan obat pada masa menyusui. Namun dalam hal ini masih terdapat pernyataan yang jawaban responden adalah salah dan tidak tahu.

Tabel 1. Statistik Deskriptif Skor Tingkat Pengetahuan Responden

\begin{tabular}{cccccc}
\hline Variabel & $\begin{array}{c}\text { Jumlah } \\
\text { responden }\end{array}$ & $\begin{array}{c}\text { Skor } \\
\text { min }\end{array}$ & $\begin{array}{c}\text { Skor } \\
\text { maks }\end{array}$ & $\begin{array}{c}\text { Rata- } \\
\text { rata } \\
\text { skor }\end{array}$ & $\begin{array}{c}\text { Std } \\
\text { deviasi }\end{array}$ \\
\hline $\begin{array}{c}\text { Tingkat } \\
\text { pengetahuan }\end{array}$ & 100 & 1 & 10 & 6,5 & 2,4 \\
\hline
\end{tabular}

Pada pernyataan pertama sebesar 36\% responden tidak mengetahui bahwa ada beberapa obat yang diminum oleh responden dapat masuk ke dalam ASI. Pada kenyataannya, terdapat beberapa obat yang dapat keluar melalui ASI meskipun dalam jumlah yang sangat rendah. Obat yang masuk ke dalam ASI dapat bervariasi tergantung pada sifat fisikokimia dari masing-masing molekul obat. ${ }^{24}$ Karakteristik obat yang dapat masuk ke dalam ASI adalah obat yang bersifat larut lemak, obat dengan ikatan protein lemah, obat yang berada dalam bentuk tidak terion, dan obat dengan berat molekul $<200$ Dalton. ${ }^{30}$

Tabel 2. Kategori Tingkat Pengetahuan Responden

\begin{tabular}{cccc}
\hline No & $\begin{array}{c}\text { Skor total berdasarkan } \\
\text { rata-rata skor } \\
\mathbf{\pm} \text { standar deviasi }\end{array}$ & $\begin{array}{c}\text { Kategori tingkat } \\
\text { pengetahuan }\end{array}$ & $\begin{array}{c}\text { Persentase } \\
\mathbf{( \% )}\end{array}$ \\
\hline $\mathbf{1}$ & $<4,1$ & Rendah & 20 \\
\hline $\mathbf{2}$ & $4,1-8,9$ & Sedang & 57 \\
\hline $\mathbf{3}$ & $>8,9$ & Tinggi & 23 \\
\hline
\end{tabular}

Pada pernyataan kedua, terdapat sebesar $46 \%$ responden yang beranggapan bahwa obat yang diperbolehkan penggunaannya pada bayi dianggap tidak dapat digunakan oleh ibu menyusui. Padahal obat yang diberi izin untuk digunakan pada bayi umumnya tidak membahayakan. ${ }^{15}$ Menurut Wells et al., (2015) strategi untuk mengurangi risiko penggunaan obat yang terekskresikan melalui ASI adalah dengan memilih obat untuk ibu menyusui yang aman digunakan pada bayi.
Sementara terkait pernyataan ketiga pada kuisioner, terdapat sebesar 23\% responden beranggapan bahwa bayi tidak perlu dipantau secara cermat terhadap efek samping yang mungkin muncul saat responden menggunakan obat. Menurut penelitian Chaves \& Lamounier (2004), terdapat beberapa aspek yang perlu diperhatikan mengenai peresepan obat terhadap ibu menyusui. Salah satunya dengan memberikan informasi kepada ibu menyusui untuk mengamati gerak bayi yang dapat dikaitkan dengan terjadinya efek samping seperti perubahan dalam pola makan bayi, perubahan pola tidur bayi, bayi resah atau gelisah, dan gangguan pencernaan.

Pada pernyataan keempat, terdapat sebesar 53\% responden yang beranggapan bahwa pemberian jarak waktu antara menyusui dan minum obat dapat meningkatkan risiko efek samping obat. Berdasarkan hasil penelitian, terdapat responden yang hanya memberikan jarak antara waktu menyusui dan minum obat selama 15 menit saja. Padahal, jarak waktu yang perlu diberikan sekitar 3-4 jam. ${ }^{41}$ Jeda waktu antara menyusui dan minum obat dapat ditentukan dengan melihat waktu paruh dari obat yang digunakan. Dengan melihat waktu paruh suatu senyawa obat, diharapkan dapat mengurangi potensi efek samping yang mungkin timbul pada bayi-bayi dimana sang ibu sedang mendapatkan terapi obat. Strategi menggunakan obat saat ibu menyusui menggunakan obat sekali dalam sehari, maka gunakan obat sebelum masa tidur bayi paling panjang misal pada malam hari. Untuk ibu menyusui yang menggunakan obat beberapa kali dalam sehari, maka penggunaan obat diberikan saat setelah selesai menyusui. ${ }^{17}$

Pernyataan selanjutnya pada kuesioner terkait usia bayi saat responden mengonsumsi obat. Berdasarkan hasil penelitian, terdapat $44 \%$ responden yang beranggapan bahwa semakin muda usia bayi maka risiko obat semakin rendah. Menurut penelitian Berlin (2013) mengatakan bahwa bayi neonatus sampai usia 2 minggu sangat rentan terhadap toksisitas suatu obat. Terdapat tiga kategori keterpaparan suatu obat pada bayi berdasarkan usia, bayi berisiko tinggi dengan usia neonatus atau $<1$ bulan, bayi berisiko sedang pada usia < dari 6 bulan dan bayi berisiko rendah pada usia 6-18. ${ }^{20}$ Semakin dini (muda) usia bayi, risiko bayi terpapar obat dan menimbulkan efek samping akan semakin besar. Hal ini berkaitan organ hati dan ginjal pada bayi yang belum berfungsi secara optimal. ${ }^{40}$

Pada pernyataan keenam yang tertera pada kuisioner, sebesar $48 \%$ responden yang beranggapan bahwa obat dalam bentuk krim atau salep lebih tidak aman untuk digunakan daripada tablet/kapsul/pil. Padahal menurut penelitian Hotham \& Hotham (2015), dalam peresepan suatu obat pada ibu menyusui perlu untuk memberikan rute alternatif agar meminimalkan responden terpapar suatu obat. Contohnya dengan memilih terapi topikal atau lokal daripada terapi oral ataupun parenteral bila memungkinkan. ${ }^{11}$ Tujuan dari pemilihan rute pemberian penggunaan obat pada ibu menyusui adalah agar dapat 
menghasilkan jumlah obat terkecil yang sampai pada bayi. ${ }^{16}$ Selain itu, sebesar $17 \%$ responden beranggapan bahwa tidak perlu bertanya kepada dokter/bidan/apoteker terkait keamanan obat yang digunakan. Padahal, jika ibu menyusui meragukan keamanan penggunaan obat pada masa menyusui, maka ibu menyusui perlu untuk mencari informasi kepada tenaga kesehatan terdekat. ${ }^{22}$

Sebesar 37\% responden beranggapan bahwa obat yang memiliki kandungan bahan aktif lebih dari satu lebih aman digunakan oleh responden. Menurut Chaves \& Lamounier (2004), obat yang mengandung satu bahan aktif saja lebih baik digunakan oleh ibu menyusui daripada obat dengan kombinasi.

Tabel 3. Profil Jawaban Responden tentang Pengetahuan Keamanan Penggunaan Obat pada Ibu Menyusui

\begin{tabular}{|c|c|c|c|c|}
\hline \multirow[t]{2}{*}{ No } & \multirow[t]{2}{*}{ Pernyataan } & \multicolumn{3}{|c|}{$\begin{array}{c}\text { Jumlah Nilai Jawaban } \\
\text { Responden n=100 (100\%) }\end{array}$} \\
\hline & & $\begin{array}{c}\text { Benar* } \\
\mathrm{n}(\%)\end{array}$ & $\begin{array}{c}\text { Salah** } \\
\mathrm{n}(\%)\end{array}$ & $\begin{array}{c}\text { Tidak } \\
\text { Tahu*** } \\
\mathrm{n}(\%)\end{array}$ \\
\hline 1 & $\begin{array}{l}\text { Beberapa obat jika } \\
\text { dikonsumsi oleh ibu } \\
\text { menyusui dapat masuk ke } \\
\text { dalam ASI dan diminum } \\
\text { oleh bayi. }\end{array}$ & $64(64)$ & $4(4)$ & $32(32)$ \\
\hline 2 & $\begin{array}{l}\text { Obat yang diberi izin } \\
\text { untuk digunakan pada } \\
\text { bayi umumnya tidak dapat } \\
\text { digunakan saat menyusui. }\end{array}$ & $54(54)$ & $12(12)$ & $34(34)$ \\
\hline 3 & $\begin{array}{l}\text { Bayi harus dipantau } \\
\text { secara cermat terhadap } \\
\text { efek samping yang } \\
\text { mungkin terjadi pada } \\
\text { masa ibu menyusui } \\
\text { menggunakan suatu obat. }\end{array}$ & 77 (77) & $8(8)$ & $15(15)$ \\
\hline 4 & $\begin{array}{l}\text { Apabila ibu memberikan } \\
\text { jarak waktu antara } \\
\text { menyusui dan minum } \\
\text { obat, risiko bayi terpapar } \\
\text { obat akan lebih besar }\end{array}$ & 47 (47) & $31(31)$ & $22(22)$ \\
\hline 5 & $\begin{array}{l}\text { Semakin dini (muda) usia } \\
\text { seorang bayi terpapar } \\
\text { obat, risiko efek samping } \\
\text { akan semakin tinggi. }\end{array}$ & $56(56)$ & $11(11)$ & $33(33)$ \\
\hline 6 & $\begin{array}{l}\text { Obat dalam bentuk tablet, } \\
\text { kapsul atau pil lebih aman } \\
\text { digunakan oleh ibu } \\
\text { menyusui dibandingkan } \\
\text { obat dalam bentuk krim } \\
\text { atau salep }\end{array}$ & $52(52)$ & $22(22)$ & $26(26)$ \\
\hline 7 & $\begin{array}{l}\text { Apabila ibu menyusui } \\
\text { ragu menggunakan obat } \\
\text { saat menyusui, sebaiknya } \\
\text { bertanya kepada dokter/ } \\
\text { bidan/ apoteker. }\end{array}$ & $83(83)$ & $12(12)$ & $5(5)$ \\
\hline 8 & $\begin{array}{l}\text { Obat yang terdiri dari } \\
\text { banyak komposisi lebih } \\
\text { aman digunakan oleh ibu } \\
\text { menyusui daripada obat } \\
\text { dengan } \\
\text { tunggal. }\end{array}$ & $63(63)$ & $8(8)$ & $29(29)$ \\
\hline 9 & $\begin{array}{l}\text { Obat yang digunakan ibu } \\
\text { menyusui sebaiknya } \\
\text { hanya untuk jangka }\end{array}$ & $75(75)$ & $13(13)$ & $12(12)$ \\
\hline
\end{tabular}

pendek atau sesekali saja

10 Ibu menyusui tidak perlu mempertimbangkan

manfaat atau risiko penggunaan obat pada masa menyusui

* Responden menjawab pernyataan dengan benar

** Responden menjawab pernyataan dengan salah

*** Responden menjawab pernyataan dengan tidak tahu

Contohnya penggunaan obat parasetamol kombinasi asetosal dan kafein sebaiknya dihindari pada ibu menyusui dengan memilih alternatif penggunaan parasetamol atau ibuprofen untuk mengatasi nyeri. Penggunaan asetosal pada ibu menyusui secara berulang harus dihindari karena dapat kemungkinan menyebabkan disfungsi trombosit dan Sindrom Reye. ${ }^{18}$

Selanjutnya sebesar $25 \%$ responden beranggapan bahwa penggunaan obat pada masa menyusui perlu digunakan terus-menerus. Padahal, penggunaan obat pada ibu menyusui sebaiknya hanya dalam jangka pendek. Kecuali, ibu menyusui yang mengalami penyakit kronis sehingga harus mengonsumsi obat dalam jangka waktu yang lama. ${ }^{22}$

Sebesar 22\% responden beranggapan bahwa tidak perlu mempertimbangkan manfaat dan risiko penggunaan obat pada masa menyusui. Padahal, penggunaan obat yang tidak diperlukan harus dihindari. Jika pengobatan memang diperlukan, perbandingan manfaat atau risiko harus dipertimbangkan pada ibu maupun bayinya. ${ }^{16}$ Ibu menyusui perlu untuk mengkomunikasikan pada saat berobat bahwa sedang menyusui, sehingga obat yang diresepkan untuk ibu menyusui sudah dipertimbangkan manfaat dan risikonya. ${ }^{11}$

Keamanan Obat yang Digunakan Pada Masa Menyusui Pada kuesioner penelitian ini terdapat pertanyaan terkait obat yang digunakan pada masa menyusui yang bertujuan untuk mengetahui kategori keamanan obat menurut WHO 2003. Responden tidak hanya dapat menyebutkan satu jenis obat, melainkan dapat lebih dari satu. Hasil yang didapatkan dari responden tentang obat yang digunakan pada masa menyusui, persentase tertinggi sebanyak 91 orang responden $(53,2 \%)$ menggunakan parasetamol, sedangkan persentase terendah masing-masing sebesar satu orang responden $(0,6 \%)$ menggunakan tetrasiklin, efedrin $\mathrm{HCl}$, dan vitamin $\mathrm{C}$ (Tabel 4).

Tabel 4. Kategori Obat yang Pernah Digunakan oleh Responden Berdasarkan Tingkat Keamanannya Sesuai Rekomendasi WHO (2003)

\begin{tabular}{ccc}
\hline Nama & Kategori & $\mathbf{n}=\mathbf{1 7 1}(\boldsymbol{\%})$ \\
\hline Amoksisilin & 1 & $5(2,9)$ \\
Asam mefenamat & 1 & $13(7,6)$ \\
Asam folat & 1 & $6(3,5)$ \\
Dextrometorphan $\mathrm{HBr}$ & 1 & $5(2,9)$ \\
Fe & 1 & $6(3,5)$ \\
Ibuprofen & 1 & $2(1,2)$ \\
Parasetamol & 1 & $91(53,2)$ \\
\hline
\end{tabular}




$\begin{array}{ccc}\text { Tetrasiklin } & 1 & 1(0,6) \\ \text { Asetosal } & 2 & 4(2,3) \\ \text { Efedrin } \mathrm{HCl} & 2 & 1(0,6) \\ \text { Vitamin C } & 2 & 1(0,6) \\ \text { Klorfenamin } & 3 & 36(21,1)\end{array}$

Dalam menggunakan obat, ibu menyusui perlu mengetahui keamanan obat yang digunakan saat mengalami keluhan. Dalam penelitian ini, untuk mengetahui tingkat keamanan obat yang digunakan oleh ibu menyusui digunakan pengelompokan menurut WHO tahun 2003 yang dibagi ke dalam lima kategori. Obat kategori satu ialah obat yang aman digunakan oleh ibu menyusui karena secara teori tidak kontraindikasi untuk digunakan, obat kategori dua adalah obat yang diperbolehkan penggunaannya pada ibu menyusui, , tetapi perlu dipantau adanya efek samping ringan pada bayi contohnya seperti gangguan tidur bayi, bayi menangis terus, diare, dan sariawan. Pada kategori tiga, jika memungkinkan obat sebaiknya dihindari penggunaannya dan perlu pemantauan terhadap adanya efek samping pada bayi contohnya seperti apnea, bradikardi, hemolisis, dan penekanan sumsum tulang belakang pada bayi. Kategori empat jika memungkinkan obat sebaiknya dihindari karena dapat menurunkan jumlah ASI yang dikeluarkan oleh responden. Obat dengan kategori lima sebaiknya dihindari penggunaannya pada ibu menyusui karena memiliki kemungkinan untuk menekan sistem imun contohnya seperti metotreksat dan doksorubisin. ${ }^{46}$

\section{Keamanan Obat Kategori Satu}

Berdasarkan hasil penelitian terdapat responden yang menggunakan amoksisilin. Amoksisilin merupakan antibiotik yang masuk ke dalam golongan penisilin. Amoksisilin aktif melawan organisme gram positif dan gram negatif tertentu. ${ }^{8}$ Penggunaan antibiotik amoksisilin berdasarkan WHO (2003) termasuk dalam kategori satu yaitu aman pada ibu menyusui.

Selain amoksisilin, responden juga menggunakan asam mefenamat yang merupakan golongan nonsteroidal anti-inflammatory drug (NSAID). Asam mefenamat digunakan oleh responden untuk mengurangi nyeri seperti sakit gigi. Asam mefenamat aman digunakan pada ibu menyusui karena secara teoritis tidak menunjukkan adanya kontraindikasi saat digunakan. ${ }^{46}$ Menurut American Academy of Pediatrics (AAP) 2001, asam mefenamat tergolong aman digunakan pada responden tanpa menunjukkan tanda atau gejala yang dilaporkan pada bayi dan efek saat menyusui. Hal ini serupa dengan Chaves (2004) bahwa asam mefenamat merupakan obat yang biasanya aman digunakan saat menyusui.

Selain itu terdapat responden yang menggunakan dekstrometorfan $\mathrm{HBr}$ yang merupakan antitusif. Tetapi, tidak terdapat laporan yang mengatakan bahwa dekstrometorfan $\mathrm{HBr}$ tidak aman pada ibu menyusui. ${ }^{28} \mathrm{Hal}$ ini sesuai dengan Toxnet dan WHO (2003) bahwa informasi yang dipublikasikan terhadap dekstrometorfan $\mathrm{HBr}$ masih belum mencukupi. Obat lain yang juga digunakan oleh responden dalam penelitian ini adalah ibuprofen. Ibuprofen memiliki keuntungan dalam manfaat dan risiko dibandingkan dengan kodein. ${ }^{38}$ Hasil dosis relatif ibuprofen pada bayi berdasarkan penelitian Rigourd (2014) yaitu < $0,38 \%$, obat dengan dosis relatif bayi $<10 \%$ dapat dikatakan obat tersebut aman digunakan oleh ibu menyusui. ${ }^{22}$ Keamanan ibuprofen sebanding dengan penelitian WHO (2003), AAP (2001), dan Chaves (2004) yang menggolongkan ibuprofen sebagai obat yang aman digunakan saat menyusui.

Parasetamol merupakan obat yang dapat mengurangi demam dan nyeri yang paling banyak digunakan oleh responden. Parasetamol dikategorikan sebagai obat yang aman digunakan oleh ibu menyusui. ${ }^{46}$ Parasetamol memiliki waktu paruh yang cukup singkat yaitu 2,6 jam. Secara teoritis konsentrasi parasetamol di dalam ASI sebesar 4,39 mg/L, konsentrasi tersebut $<0,1 \%$ dari dosis yang digunakan ibu menyusui yaitu 500 mg. ${ }^{18}$ Menurut Drug Information Handbook (DIH), dosis parasetamol yang diperbolehkan digunakan oleh bayi dengan usia 0-3 bulan adalah $40 \mathrm{mg}$, sehingga obat yang masuk melalui ASI berdasarkan teoritis kurang dari $40 \mathrm{mg}$ yang artinya parasetamol aman digunakan oleh responden.

Menurut penelitian Matheson (1985), ditemukan suatu laporan dimana penggunaan parasetamol dapat menyebabkan maculopapular rash (ruam makulopapular) pada bayi yang berusia dua bulan, hal ini dikaitkan dengan adanya parasetamol dalam ASI. Dosis parasetamol yang digunakan oleh responden menurut kasus adalah 1 gram sebelum tidur selama dua hari. Pada penelitian ini, ibu menyusui yang menggunakan parasetamol memiliki bayi berusia di atas dua bulan, tetapi terdapat satu ibu menyusui yang menggunakan parasetamol dengan usia bayi lima hari.

Pada masa menyusui, ibu perlu memerhatikan asupan energi. Hal ini dihubungkan dengan kebutuhan gizi yang tinggi, kebutuhan gizi yang tinggi diperlukan untuk memproduksi ASI dan menjaga kualitas dan kuantitas ASI agar pertumbuhan bayi optimal. ${ }^{19}$ Kurangnya asupan energi oleh responden menyebabkan penggunaan suplemen diperlukan, berdasarkan penelitian terdapat responden menggunakan Sangobion ${ }^{\circledR}$. Suplemen sangobion mengandung asam folat dan $\mathrm{Fe}$ yang aman digunakan pada ibu menyusui. ${ }^{46}$

Selain itu, terdapat responden yang menggunakan obat Supertetra ${ }^{\circledR}$ pada masa menyusui. Kandungan dari Supertetra $^{\circledR}$ adalah tetrasiklin, menurut WHO (2003) penggunaan tetrasiklin aman pada responden. Hal ini berbeda menurut British National Formulary Children (BNFC) tahun 2009 bahwa penggunaan tetrasiklin pada responden perlu dihindari meskipun absorpsi dan kemungkinan perubahan warna gigi pada bayi dapat dicegah oleh kelasi dengan kalsium dalam ASI. Tetrasiklin merupakan antibiotik spektrum luas yang merupakan pilihan untuk infeksi yang disebabkan oleh klamidia. ${ }^{8}$ 


\section{Keamanan Obat Kategori Dua}

Obat dengan kategori dua di sini boleh digunakan oleh ibu menyusui, tetapi perlu untuk memerhatikan adanya efek samping ringan berupa gangguan tidur, bayi menangis terus-terusan, mengantuk, dan diare. ${ }^{46}$ Obat yang masuk dalam kategori dua disebabkan mengandung bahan obat yang dapat menyebabkan efek samping ringan. Pada penelitian ini, terdapat responden yang menggunakan obat yang masuk ke dalam kategori dua. Kebanyakan obat yang digunakan oleh responden terdiri dari banyak komposisi. Berikut obat yang masuk dalam kategori kedua seperti asetosal, efedrin $\mathrm{HCl}$, dan vitamin $\mathrm{C}$.

Menurut WHO (2003) asetosal aman digunakan oleh responden, tetapi perlu dihindari jika penggunaan asetosal dalam jangka panjang. Selain itu, perlu pemantauan efek samping pada bayi seperti hemolisis, pendarahan terusmenerus, dan asidosis metabolik. Penggunaan asetosal umumnya memang tidak dianjurkan untuk mengobati nyeri pada masa menyusui. Hal ini dapat memungkinkan adanya efek samping yang signifikan pada bayi, karena dosis relatif asetosal pada bayi $>10 \%$ sehingga perlu memilih alternatif yang lebih aman seperti parasetamol atau ibuprofen. Asetosal secara teoritis juga dapat menyebabkan Sindrom Reye pada bayi jika dosis asetosal yang digunakan > $500 \mathrm{mg} /$ hari. Jika ibu menyusui menggunakan dosis asetosal yang rendah 50-300mg/hari, maka ada kemungkinan tidak menimbulkan adanya efek samping. ${ }^{18}$

Efedrin $\mathrm{HCl}$ merupakan dekongestan yang membantu untuk meringankan hidung tersumbat. Penggunaan efedrin $\mathrm{HCl}$ pada ibu menyusui aman digunakan, tetapi perlu memantau adanya efek samping berupa gangguan tidur atau bayi mudah menangis. ${ }^{46}$ Selain penggunaan obat terdapat satu responden yang menggunakan vitamin C. Menurut WHO (2003) vitamin C aman digunakan pada responden dalam dosis biasa. Apabila dosis yang ibu menyusui gunakan adalah dosis besar, perlu pemantauan adanya efek samping seperti hemolisis dan jaundice.

\section{Keamanan Obat Kategori Tiga}

Obat dengan kategori ketiga jika memungkinkan sebaiknya dihindari penggunaannya pada ibu menyusui, serta ibu menyusui perlu untuk memerhatikan adanya efek samping pada bayi ${ }^{46}$ Obat yang masuk dalam kategori tiga mengandung bahan obat yang dapat menyebabkan efek samping. Kandungan klorfeniramin maleat dalam obat kombinasi menyebabkan obat tersebut masuk dalam kategori tiga.

Klorfeniramin maleat merupakan antihistamin generasi pertama dan dianggap aman digunakan pada masa menyusui serta tidak memberikan efek yang tidak diinginkan pada bayi yang sedang disusui. Tetapi, terdapat laporan bahwa $10 \%$ bayi mengalami gejala kolik dan bayi mudah menangis setelah terpapar antihistamin. Selain itu terdapat efek samping lain yang dialami berupa kantuk pada bayi. Terjadinya efek samping tersebut diakibatkan karena ibu menyusui menggunakan antihistamin dalam jangka panjang. ${ }^{35}$ Menurut Nice (2000) untuk menghindari adanya potensi efek samping yang tidak diinginkan, cara terbaik menggunakan antihistamin adalah waktu bayi tidur paling lama atau setelah menyusui. Obat kombinasi yang mengandung klorfeniramin maleat yang digunakan oleh responden yaitu Coloratusin ${ }^{\circledR}$, Demacolin ${ }^{\circledR}$, Konidin ${ }^{\circledR}$, Mixagrip ${ }^{\circledR}$, OBH Combi ${ }^{\circledR}$, Paratusin $^{\circledR}$, dan Ultraflu ${ }^{\circledR}$.

Obat dengan kategori tiga ini telah dilaporkan dapat menyebabkan efek samping pada bayi sehingga alternatifnya menggunakan loratadin atau cetirizin sebagai antihistamin untuk ibu menyusui. ${ }^{33}$ Ibu menyusui dapat menggunakan obat kategori tiga apabila benar-benar penting dan tidak terdapat alternatif yang lebih aman. ${ }^{46}$ Peran tenaga kesehatan sangat dibutuhkan untuk memberikan instruksi yang jelas tentang pentingnya mengamati adanya efek samping pada bayi dan ibu menyusui perlu mengatur jadwal saat mengonsumsi obat.

\section{Keamanan Obat Diluar Kategori WHO}

Pada penelitian ini juga terdapat daftar obat yang kategori keamanannya belum terdapat pada kategori keamanan obat yang dimiliki oleh WHO. Terdapat responden yang menggunakan Entrostop ${ }^{\circledR}$ yang merupakan obat antidiare. Entrostop ${ }^{\circledR}$ memiliki kandung attapulgit dan pektin. ${ }^{34}$ Sediaan obat antidiare yang mengandung attapulgit aman digunakan ketika menyusui. Tidak terdapat data tentang ekskresi attapulgit masuk ke dalam ASI, karena attapulgit dan pektin tidak diabsorpsi secara sistemik. ${ }^{36}$ Selain itu, untuk mengatasi keluhan diare responden juga menggunakan Diapet ${ }^{\circledR}$ yang didapatkan di warung terdekat maupun apotek. Kandungan komposisi Diapet $^{\circledR}$ adalah ekstrak Psidii folium, ekstrak Curcumae domesticae rhizoma, ekstrak Coixlacrima jobi semen, ekstrak Phellodendri radix dan ekstrak Coptidis rhizoma. ${ }^{23}$ Phellodendri adalah salah satu tanaman untuk mengobati diare, Phellodendri dapat digunakan setelah satu bulan pertama menyusui. Berdasarkan hasil penelitian, rata-rata usia bayi lebih dari satu tahun untuk responden yang menggunakan Diapet ${ }^{\circledR}$. Curcumae domesticae atau Curcumae longae aman digunakan oleh responden, hanya penggunaannya dilarang pada masa hamil. ${ }^{21}$ Penggunaan Coptidis menurut Hempen \& Fischer (2009) dilarang untuk ibu yang sedang hamil, tetapi tidak terdapat larangan untuk ibu menyusui.

Pada penelitian ini juga terdapat responden yang mengobati keluhan dengan obat Promag $^{\circledR}$. Promag ${ }^{\circledR}$ merupakan obat golongan antasida yang dapat menetralkan asam lambung. Penggunaan Promag ${ }^{\circledR}$ yang mengandung hidrotalsit, Mg-hidroksida, dan simetikon aman digunakan oleh responden, karena bayi hanya akan terpapar magnesium dalam jumlah yang rendah. ${ }^{36}$ Sehingga Promag ${ }^{\circledR}$ dapat dikategorikan dengan kategori aman penggunaannya pada ibu menyusui. Selain itu, terdapat responden yang menggunakan obat Antalgin ${ }^{\circledR}$. Antalgin ${ }^{\circledR}$ atau yang dikenal dengan dipiron dapat menyebabkan sianosis pada bayi 
dengan dosis $500 \mathrm{mg}$ tiga kali sehari. ${ }^{39}$ Menurut penelitian Rizzoni \& Furlanut (1984), kondisi tersebut dapat terjadi pada bayi berusia 42 hari. Pada penelitian ini, hanya terdapat tiga responden yang menggunakan Antalgin ${ }^{\circledR}$ untuk mengatasi keluhan nyeri. Usia bayi untuk kedua responden berada lebih dari 42 hari, tetapi terdapat usia bayi pada salah satu responden yang kurang dari 42 hari yaitu berusia 29 hari. Ibuprofen dan parasetamol dapat digunakan sebagai alternatif pilihan untuk responden dalam mengatasi nyeri.

Kafein merupakan kandungan obat yang paling banyak digunakan oleh responden. Banyak obat OTC (over the counter) yang mengandung kafein khususnya obat analgesik. Ibu menyusui yang mengonsumsi minuman yang kaya dengan kafein, telah diketahui menunjukkan agitasi (keresahan) pada bayi, bayi kurang tidur dan bayi mudah menangis. ${ }^{14}$ Hal ini dibenarkan oleh AAP (2001) bahwa kafein aman digunakan pada responden tetapi perlu untuk memerhatikan adanya efek samping seperti bayi kurang tidur dan bayi mudah menangis. Penggunaan kafein kurang dari $300 \mathrm{mg}$ merupakan batas aman untuk responden. ${ }^{14}$ Menurut Nice et al., (2000), obat kombinasi analgesik yang mengandung kafein sebaiknya dihindari pada ibu menyusui, sebagai alternatif dapat digunakan analgesik tanpa kombinasi kafein seperti ibuprofen atau parasetamol. Selain obat yang mengandung kafein, terdapat responden yang menggunakan obat yang di dalamnya terkandung fenilpropanolamin. Fenilpropanolamin merupakan dekongestan yang dapat menyebabkan vasokonstriksi pada saluran pernapasan, sehingga mengakibatkan pengurangan mukus di dalam hidung. Fenilpropanolamin dapat berpotensi memberikan efek pada bayi yang disusuinya berupa bayi mudah menangis, insomnia (bayi kesulitan untuk tidur), dan takikardi.

Pilihan alternatif lainnya selain fenilpropanolamin yaitu menggunakan pseudoefedrin yang cukup kompatibel digunakan oleh ibu menyusui. ${ }^{28}$ Penggunaan pseudoefedrin $60 \mathrm{mg}$ empat kali sehari dapat menurunkan jumlah ASI sebesar 24\%. Dosis tunggal pseudoefedrin juga dapat secara signifikan menurunkan produksi ASI, tetapi dosis relatif pseudoefedrin $<10 \%$ dosis ibu. Pseudoefedrin tidak mungkin memberikan efek samping pada bayi tetapi hanya menekan jumlah ASI yang dikeluarkan. ${ }^{1}$ Responden yang menggunakan pseudoefedrin disarankan untuk menambah konsumsi cairan. ${ }^{36}$

Doksilamin merupakan antihistamin generasi pertama, tetapi antihistamin seperti doksilamin digunakan untuk pengobatan mual dan muntah. ${ }^{35}$ Selain untuk pengobatan mual dan muntah doksilamin merupakan obat yang dapat membantu pola tidur yang terganggu. ${ }^{36}$ Doksilamin yang digunakan oleh satu orang responden terkandung dalam obat Vicks Formula $44^{\circledR}$. Penggunaan doksilamin pada responden menurut Nice et al., (2000) umumnya dianggap tidak aman sehingga penggunaannya harus dihindari. Obat alternatif lain yang dapat membantu pola tidur yang terganggu adalah difenhidramin, tetapi ibu menyusui perlu memantau adanya kantuk pada bayi. ${ }^{36}$
Menurut Toxnet, dosis kecil doksilamin tidak diharapakan dapat menyebabkan efek yang tidak diinginkan pada bayi yang mendapatkan ASI, tetapi dosis yang lebih besar dan penggunaan dalam jangka panjang dapat menyebabkan sedasi (kantuk) pada bayi.

Pada penelitian ini, terdapat responden yang menggunakan obat kombinasi mengandung guaifenesin. Guaifenesin merupakan ekspektoran yang bekerja dengan mengencerkan dahak di saluran pernapasan, , sehingga dapat melegakan pernafasan. ${ }^{28}$ Penggunaan guaifenesin bagi ibu menyusui menurut Nice et al., (2000) belum terdapat laporan adanya efek yang tidak diinginkan pada bayi. Selanjutnya adalah penggunaan propifenazon pada responden. Propifenazon dapat memberikan efek analgesik dan antipiretik. Menurut Anderson (2003), penggunaan propifenazon kemungkinan dapat menyebabkan anemia hemolitik pada bayi yang ibunya mendapat terapi propifenazon. Propifenazon dapat terdeteksi di dalam plasma bayi pada fase akut hemolisis, dan masih dapat terdeteksi di dalam ASI dalam 8 hari setelah berhenti menggunakan pengobatan. Penggunaan ibuprofen atau parasetamol dapat menjadi alternatif dari penggunaan propifenazon. ${ }^{18}$

Terdapat pula responden yang menggunakan obat kombinasi yang di dalamnya terdapat noscapin. Noscapin merupakan obat golongan antitusif. Penggunaan noscapin sebaiknya diganti dengan dekstrometorpan untuk mengatasi batuk kering. Noscapin bukan merupakan antitusif yang ideal jika digunakan oleh ibu menyusui. Hal ini dikarenakan noscapin memiliki sifat mutagenik yang dikaitkan dengan adanya noscapin di dalam ASI. ${ }^{33}$

Pada penelitian ini terdapat responden yang menggunakan jamu dengan kandungan purwoceng yang diproduksi oleh Pabrik Jamu Sidowaras. Menurut informasi dari BPOM (2010), selain kandungan purwoceng, pada jamu ini juga positif mengandung bahan kimia obat (BKO) yaitu fenilbutason serta tidak memiliki izin edar. Fenilbutason memiliki waktu paruh yang cukup panjang yaitu 30-170 jam tetapi, tidak terdapat informasi yang rinci tentang keamanan fenilbutason bagi ibu menyusui. Namun, waktu paruh yang lama dapat berpotensi memberikan efek samping yang serius seperti gangguan hematologi dan gangguan pada organ ginjal, sehingga penggunaan fenilbutason pada ibu menyusui perlu diganti dengan memberikan alternatif lain yang lebih aman. Parasetamol dan ibuprofen dapat menjadi pilihan pada masa menyusui, sehingga fenilbutason sebaiknya dihindari. ${ }^{18}$ Saat ini, jamu tersebut sudah ditarik peredarannya oleh BPOM.

\section{Daftar Pustaka}

1. Aljazaf K., Hale WT., Ilett KF. Pseudoephedrine: effects on milk production in women and estimation of infant exposure via breastmilk. British Journal of Clinical Pharmacology. 2003 Jul ; 56(1):18-24. 
2. American Academy of Pediatrics. The transfer of drug and other chemicals into human milk. Pediatrics. 2001 Sep ; 108(3):776-789.

3. Anderson PO., Pochop SL. \& Manoguerra AS. Adverse drug reaction in breastfed infants: less than imagined. Clinical Pediatrics. 2003 May ; 42(4):325340.

4. Anief M. Prinsip umum dan dasar farmakologi. Yogyakarta: Gadjah Mada University Press; 2004.

5. Badan Pengawas Obat dan Makanan Republik Indonesia. Public warning obat tradisional dan suplemen makanan tahun 2001-juni 2010. Jakarta: Direktorat Inspeksi dan Sertifikasi; 2010.

6. Berlin CM. Drugs and chemicals in human milk. Seminars in Fetal and Neonatal Medicine. 2005 Apr ; 10(2):149-159.

7. Berlin CM. Medication and the breastfeeding mother. Clinical pharmacology during pregnancy (treatment options and risk assessment). Third Edition. United Kingdom : Academic Press; 2013.

8. BNFC org. British national formulary for children. London UK: British Medical Publishing Group Ltd; 2009.

9. Breitzka RL., Sandritter TL. \& Hatzopoulos FK. Principles of drug transfer into breast milk and drug disposition in the nursing infant. Journal of human lactation. 1997 Jun; 13(2):155-158.

10. Burns KE., et al. A guide for the design and conduct of self-administered surveys of clinician. Canadian Medical Association Journal. 2008 Jul; 179(3):245252.

11. Chaves RG., \& Lamounier AJ. 2004. Breastfeeding and maternal medication. Jornal de Pediatria. 2004 Nov; 80(5):189-198.

12. Chaves RG., Lamounier AJ \& Cesar CC. Selfmedication in nursing mothers and its influence on the duration of breastfeeding. Jornal de Pediatria. 2009 Apr; 85(2):129-134.

13. Davanzo R., Copertino M., Cunto AD., Minen F., Amaddeo A. Antidepressant drug and breastfeeding: a review of the literature. Breastfeeding Medicine. 2011 Apr ; 6(2):89-98.

14. Davanzo R., Bua J., Paloni G., Facchina G. Breastfeeding and migraine drugs. European Journal of Clinical Pharmacology. 2014 Nov ; 70(11):13131324.

15. Departemen Kesehatan Republik Indonesia. 2002. Manajemen laktasi buku pedoman bagi bidan dan petugas kesehatan di puskesmas. Jakarta: Direktorat Jenderal Bina Kesehatan Masyarakat.

16. Departemen Kesehatan Republik Indonesia. Pedoman Pelayanan Farmasi untuk Ibu Hamil dan Menyusui. Jakarta: Direktorat Jenderal Bina Farmasi Komunitas dan Klinik; 2006.

17. Dipiro JT., et al. Pharmacotherapy handbook, Seventh Edition. New York: Mc Graw-Hill Inc; 2009.

18. Ellfolk M. \& Hultzcsh S. Analgesic, antiphlogistic and anesthetics. drugs during pregnancy and lactation (treatment options and risk assessment). Third Edition. United Kingdom: Academic Press; 2015.

19. Fikawati S., Syafiq A., Purbaningrum PR., Karima K. 2014. Energy consumption of lactating mother: current situation and problems. Makara Journal of Health Research. 2014 Aug ;18(2): 58-64.

20. Hale TW. Maternal medication during breastfeeding. Clinical Obstetrics and Gynecology. 2004 Sep; 47(3): 696-711.

21. Hempen CH. \& Fiscer T. A materia medica for chinese medicine: plants, minerals, and animal products. English: Churchill Livingstone Elsevier; 2009.

22. Hotham N. \& Hotham E. Drugs in breastfeeding. Australian Prescriber. 2015 Oct; 38:156-159

23. Ikatan Apoteker Indonesia. Informasi Spesialite Obat Volume 47. Jakarta: Penerbit ISFI; 2013.

24. Ilett KF. \& Kristensen JH. Drug use and breastfeeding. Expert Opinion on Drug Safety, 2005 Jul ; 4(4):745-768.

25. Ito S., Blajchman A., Stephenson M., Eliopoulos C., Koren G. Prospective follow-up of adverse reaction in breast-fed infants exposed to maternal medication. American Journal of Obstetrics and Gynecology. 1993 May; 168(5):1393-1399.

26. Ito S., Koren G. \& Einarson TR. Maternal noncompliance with antibiotics during breastfeeding. The Annals of Pharmacotherapy. 1993 Jan ; 27(1): 4042.

27. Ito S. \& Lee A. Drug excretion into breast milk overview. Advanced Drug Delivery Reviews. 2003 Apr ; 55(5): 617-627.

28. Jennifer L.M. Use of cough and cold preparations during breastfeeding. Journal of Human Lactation. 1999 Des; 15 (4):347-349.

29. Joyce K.L. Pharmacology: a nursing process approach. saunders: Saunders Company. Terjemahan oleh P. Anugerah. The Annals of Pharmacotherapy. Jakarta: Buku Kedokteran EGC; 1996.

30. Lee KG. Lactation and drugs. Paediatrics and Child Health. 2007 Feb; 17(2): 68-71.

31. Marry MJ., Richard AH. \& Pamela CC. Lippicott's Illustrated Review: Pharmacology. Philadelphia: : Lippicott-Raven Publisher. Terjemahkan oleh A. Agoes. 2001. Farmakologi Ulasan Bergambar. Cetakan Pertama. Jakarta: Widya Medika; 2001.

32. Matheson I, Lunde P.K.M, Notarianni L. Infant rash caused by paracetamol in breast milk. Pediatrics. 1985 Oct; 76(4):651-652. 
33. Merlob P. \& Schondorfer CW. Antiallergics, Antiasthmatics and antitussives. Drugs During Pregnancy and Lactation (treatment options and risk assessment). Third Edition.United Kingdom: Academic Press; 2015.

34. MIMS. Mims (Monthly Index of Medical Specialities) Indonesia Petunjuk Konsultasi. Edisi 12: Jakarta. Penerbit Bhuana Ilmu Populer; 2013.

35. Miranda ,Bozzo P., Inoue M. \& Einarson A. Safety of antihistamines during pregnancy and lactation. Canadian Family Physician. 2010 May; 56(5):427429.

36. Nice FJ., Snyder JL., Kotansky BC. Review: breastfeeding and over the counter medication. Journal of Human Lactation. 2000 Nov; 16(4):319331.

37. Pradipta MH. Survei pengetahuan dan pilihan pengobatan acne vulgaris di kalangan mahasiswa kesehatan universitas jember. Skripsi. Jember: Fakultas Farmasi Universitas Jember; 2017.

38. Rigourd V., et al. Ibuprofen concentration in human mature milk-first data about pharmacokinetics study in breast milk with AOR-10127 "antalait" study. Therapeutic Drug Monitoring. 2014 Oct ; 36(5):590596.

39. Rizzoni G. \& Furlanut M. Cyanotic crises in breastfed infant from mother taking dipyrone. SAGE Journals. 1984 Nov; 3(6):505-507.

40. Schaefer C. \& Lawrence RA. Drugs during pregnancy and lactation (treatment options and risk assessment). Third Edition. United Kingdom: Academic Press; 2015.

41. Soetjaningsih D. ASI petunjuk untuk tenaga kesehatan. 2nd. Jakarta: EGC; 1997.

42. Sriningsih I. Faktor demografi, pengetahuan ibu tentang air susu ibu dan pemberian ASI eksklusif. Jurnal Kesehatan Masyarakat. 2011 ; 6(2):100-106.

43. Toxicology data network (TOXNET). Drugs and Lactation Database (LactMed). Bethesda (MD). US National Library of Medicine Institute of Health; 2017 $\begin{array}{llll}\text { [dikutip } & 1 & \text { Juli } & \text { 2017]. }\end{array}$ https://toxnet.nlm.nih.gov/newtoxnet/lactmed.htm.

44. Wells GB., Dipiro JT., Schwinghammer TL. \& Dipiro CV. Pharmacotherapy handbook Ninth Edition. New York: Mc Graw Hill Education Inc; 2015.

45. World Health Organization. 2002. Infant and young child nutrition global strategy on infant and young child feeding. Geneva: World Health Organization.

46. World Health Organization. 2003. Breastfeeding and maternal medication. Departemen of Child and Adolescent Health and Development : World Health Organization.

47. World Health Organization. 2011. Exclusive breastfeeding for six months best for babies everywhere. Geneva: World Health Organization. 